Review article

\title{
Resistance to trimethoprim and sulfonamides
}

\author{
Ola SKÖLD* \\ Division of Microbiology, Department of Pharmaceutical Biosciences, Biomedical Center, \\ Uppsala University, PO Box 581, SE-751 23 Uppsala, Sweden
}

(Received 7 December 2000; accepted 7 February 2001)

\begin{abstract}
Summary - Sulfonamides and trimethoprim have been used for many decades as efficient and inexpensive antibacterial agents for animals and man. Resistance to both has, however, spread extensively and rapidly. This is mainly due to the horizontal spread of resistance genes, expressing druginsensitive variants of the target enzymes dihydropteroate synthase and dihydrofolate reductase, for sulfonamide and trimethoprim, respectively. Two genes, sul1 and sul2, mediated by transposons and plasmids, and expressing dihydropteroate synthases highly resistant to sulfonamide, have been found. For trimethoprim, almost twenty phylogenetically different resistance genes, expressing druginsensitive dihydrofolate reductases have been characterized. They are efficiently spread as cassettes in integrons, and on transposons and plasmids. One particular gene, $d f r 9$, seems to have originally been selected in the intestine of swine, where it was found in Escherichia coli, on large plasmids in a disabled transposon, Tn5393, originally found in the plant pathogen Erwinia amylovora. There are also many examples of chromosomal resistance to sulfonamides and trimethoprim, with different degrees of complexity, from simple base changes in the target genes to transformational and recombinational exchanges of whole genes or parts of genes, forming mosaic gene patterns. Furthermore, the trade-off, seen in laboratory experiments selecting resistance mutants, showing drugresistant but also less efficient (increased $\mathrm{K}_{\mathrm{m}} \mathrm{s}$ ) target enzymes, seems to be adjusted for by compensatory mutations in clinically isolated drug-resistant pathogens. This means that susceptibility will not return after suspending the use of sulfonamide and trimethoprim.
\end{abstract}

sulfonamides / trimethoprim / resistance / plasmid / chromosome

Résumé - Résistance au triméthoprime et aux sulfamides. Les sulfamides et le triméthoprime ont été utilisés pendant plusieurs décennies en tant qu'agents antibactériens efficaces et bon marché, chez l'animal et chez l'homme. Cependant, la résistance à ces deux agents s'est propagée largement et rapidement. Ceci a surtout été dû à la propagation horizontale de gènes de résistance exprimant des variants des enzymes cibles dihydropteroate synthase et dihydrofolate réductase insensibles aux sulfamides et triméthoprime, respectivement. Deux gènes, sul1 et sul2, portés par des transposons et des plasmides, et exprimant des dihydropteroate synthases hautement résistantes aux sulfamides, ont été trouvés. Pour le triméthoprime, une vingtaine de gènes de résistance, phylogénétiquement séparés, exprimant des dihydrofolates réductases insensibles à l'antibactérien, ont été caractérisés. Ils se

* Correspondence and reprints

Tel.: (46) 18 4714500; fax: (46) 18 502790; e-mail: Ola.Skold@ farmbio.uu.se 
propagent efficacement sous forme de cassettes dans des intégrons, et sur des transposons et des plasmides. Un gène particulier, $d f r$, semble avoir été sélectionné à l'origine dans l'intestin de porc, où il a été trouvé chez Escherichia coli, dans de grands plasmides sur un transposon non fonctionnel Tn5393, initialement trouvé chez Erwinia amylovora, agent pathogène de plante. Il existe également de nombreux exemples de résistance chromosomique aux sulfamides et au triméthoprime, avec divers degrés de complexité, allant des simples changements de bases dans les gènes cibles aux échanges par transformation et recombinaison de gènes entiers ou de parties de gènes, formant des structures de gènes en mosaïque. De plus, la moindre efficacité des enzymes cibles résistantes aux antibiotiques ( $\mathrm{K}_{\mathrm{m}}$ augmenté), remarquée dans les expériences de laboratoire visant à sélectionner des mutants résistants, semble être contre-balancée par des mutations compensatoires chez les agents pathogènes résistants aux antibiotiques isolés de cas cliniques. Ceci signifie qu'il n'y aura pas de retour vers la sensibilité après un arrêt de l'utilisation des sulfamides et du triméthoprime.

sulfamides / triméthoprime / résistance / plasmide / chromosome

Table of contents

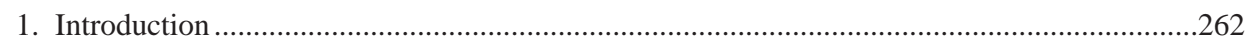

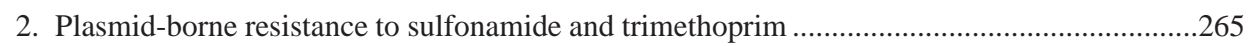

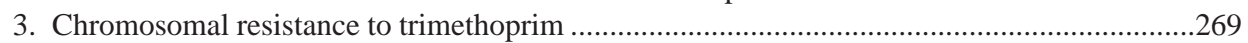

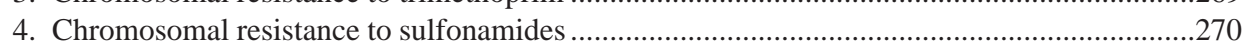

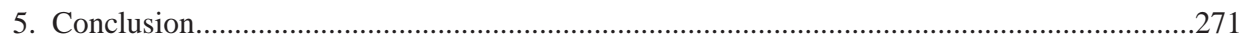

\section{INTRODUCTION}

Sulfonamides represent the oldest, and trimethoprim the most recently introduced antibacterial agents. The first tests showing that mice experimentally infected with Streptococcus pyogenes in the abdominal cavity could be protected from developing peritonitis by a chemically synthesized sulfonamide (Prontosil rubrum; 4-sulfonamide2',4'-diaminoazobenzene, hydrolyzed in vivo to sulfanilamide) were performed in 1932 and published in 1935 by Gerhard Domagk [7]. Trimethoprim was first used in England in 1962 [18] and is actually the last truly new antibacterial agent introduced into clinical practice. All later agents have been variations of older antibacterial remedies, that is, belonging to families of agents, within which cross-resistance is common. The next truly new antibacterial agent would be linezolid [39], the oxazolidinone soon to be introduced in Europe.

The great, 60-year-old asset of antibacterial drugs enabling the control of bacte- rial disease in human medicine and animal husbandry is constantly eroded by the development and spread of drug resistance. This development is a consequence of the dramatic change in microbial environment that the ubiquitous use of antibacterial drugs has resulted in. There are figures to say that one to ten million tons of antibiotics have been distributed in the biosphere during the era of remedial control of bacterial infections. Microbes have reacted to this assault of man-made poisons by adapting themselves to the changed environment, that is, by developing resistance. This adaptive evolution has been impressively rapid, which is mainly due to a horizontal and promiscuous flow of resistance genes among bacteria. The widespread resistance to sulfonamides and trimethoprim is a good example of this. Mechanisms of resistance to both of these drugs include resistance genes of many though unknown origins, and are extensively spread among many bacterial species in many geographical areas by genetic pathways, that in most cases are well-known. 
The synthetic sulfonamides are, from a microbiological point of view, a single agent, working by structural analogy with p-aminobenzoic acid in the biosynthetic pathway leading to folic acid (Figs. 1 and

2). Sulfonamide competitively inhibits the<smiles></smiles>

Figure 1. Chemical formulas for sulfonamide (upper), trimethoprim (lower) and dihydrofolic acid (middle) demonstrating structural similarities related to competitive inhibition.<smiles>COc1ccc(N)cc1</smiles>

p-aminobenzoic acid<smiles>Nc1ccc(S(=O)(=O)Nc2ncccn2)cc1</smiles>

Sulfadiazine<smiles>Nc1ccc(S(=O)(O)(O)Nc2nccs2)cc1</smiles>

\section{Sulfathiazole}<smiles>Nc1ccc(S(=O)(=O)Nc2cncc(Cl)n2)cc1</smiles>

Sulfaclozine<smiles>Cc1cc(NS(O)(O)c2ccc(N)cc2)no1</smiles>

Sulfamethoxazole

Figure 2. Chemical structures of a few sulfonamides and paraaminobenzoic acid. 
bacterial enzyme dihydropteroate synthase (DHPS) catalyzing the next to last step, and the condensation of p-aminobenzoic acid (PABA) and 7,8-dihydro-6-hydroxymethylpterin-pyrophosphate to dihydropteroic acid, in the reaction sequence leading to dihydrofolic acid.

Trimethoprim is also a synthetic antibacterial agent belonging to the diaminopyrimidine group of compounds. It can be regarded as an antifolate, a structural analog of folic acid (Fig. 1) competitively inhibiting the reduction of dihydrofolate to tetrahydrofolate by dihydrofolate reductase (DHFR), an enzymic reaction, that all living cells are dependent on, among other things, for their synthesis of DNA thymine.
Sulfonamide and trimethoprim very selectively act on prokaryotic bacterial cells, leaving mammalian cells unaffected. Sulfonamide cannot interact with mammalian cells because these cells do not synthesize folic acid, and thus have no dihydropteroate synthase target enzyme. Instead they take up folic acid from their environment, which most bacteria cannot do because they lack a transport system for this purpose.

Trimethoprim, aminopterin and methotrexate are antifolates (Fig. 3), but only trimethoprim selectively affects bacterial cells and does not interfere with mammalian cells, even at concentrations ten thousandfold higher than the MIC-values found for most bacteria. The reason for this difference<smiles>COc1cc(Cc2cnc(N)nc2N)cc(OC)c1OC</smiles>

Trimethoprim<smiles>CN(Cc1cnc2nc(N)nc(N)c2n1)c1ccc(C(=O)N[C@@H](CCC(=O)O)C(=O)O)cc1</smiles>

Methotrexate

Figure 3. Chemical formulas of trimethoprim, aminopterin and methotrexate demonstrating structural similarities with dihydrofolic acid (Fig. 1).

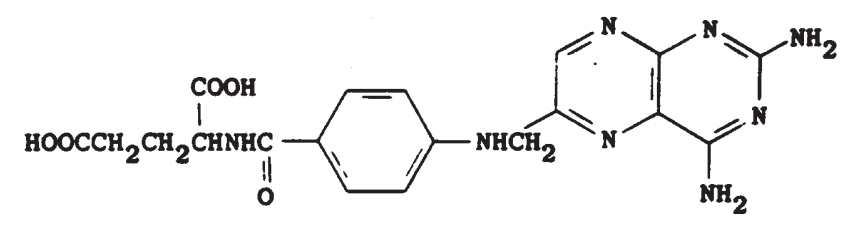

Aminopterin 
has been investigated by X-ray crystallography studies, showing that trimethoprim fits well in the nucleotide-binding site of the dihydrofolate reductase from Escherichia coli for example, but not in the corresponding site of the mammalian enzyme [26].

Resistance to sulfonamide among pathogenic bacteria appeared quite soon after its introduction into clinical practice in the 1930s, and resistance to the much younger drug trimethoprim is quite frequent today [19].

The total use of sulfonamide and trimethoprim, respectively, for veterinary purposes in Sweden, has been rather constant during the last four years. It has amounted to about 2300 kilograms of sulfonamide and roughly 400 kilograms of trimethoprim per year [28].

\section{PLASMID-BORNE RESISTANCE TO SULFONAMIDE AND TRIMETHOPRIM}

Since sulfonamide and trimethoprim are synthetic antibacterial agents, naturally occurring enzymes degrading or modifying these drugs should not be expected. Plasmid-mediated resistance to sulfonamide and trimethoprim is instead caused by nonallelic and drug-resistant variants of the chromosomal target enzymes dihydropteroate synthase and dihydrofolate reductase, respectively $[33,35,46]$. A stylized representation of this mechanism is shown in Fig. 4. Two genes, sul1 and sul2, coding for drug-resistant dihydropteroate synthases are known $[29,37,40]$. The sul1 gene is mostly

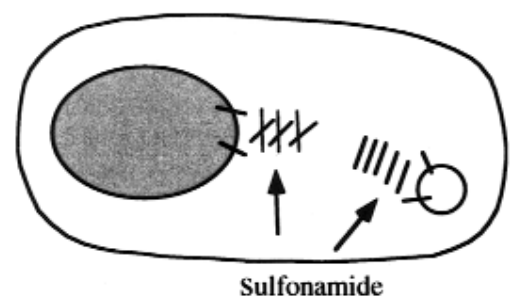

Drugresistant variations of the folate-forming enzyme dihydropteroate synthase (DHPS)

MIC

E. coli $<0.01 \mathrm{mM}$

E. coli (sul 1) $2.00 \mathrm{mM}$

Figure 4. Cartoon demonstrating plasmid-borne resistance to sulE.coli (sul 2) $\quad>4.00 \mathrm{mM}$ fonamide (upper part) and to trimethoprim (lower part). In the stylized bacterial cells, the chromosomes are represented by filled circular structures, and plasmids by small circles. The chromosomal target enzymes are knocked out by the drugs (crossed bars), but resistant bacterial cells could grow, relying on drug-insensitive, variants of these enzymes expressed from plasmid-mediated genes.

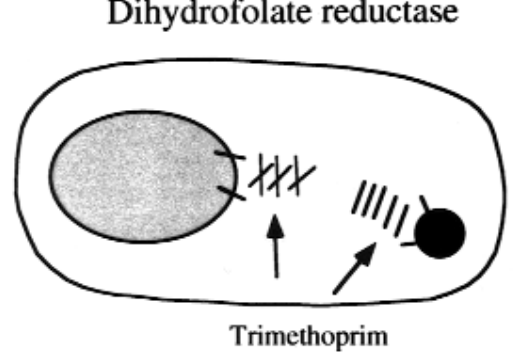


found linked to other resistance genes in class 1 integrons, while sul2 is usually located on small plasmids of the inc $\mathbf{Q}$ incompatibility group, or on another type of small plasmids represented by pBP1 [45]. The sul1 and sul2 genes are often found at equal frequencies among sulfonamide resistant, Gram-negative clinical isolates [30]. The origin of these genes, presumably other microorganisms, is unknown.

Surprisingly, only two plasmid-borne genes, sul1 and sul2, have been found to be associated with the long known and very common sulfonamide resistance in Gramnegative bacteria. This could be due to the fact that they are both located on very efficient vehicles for dissemination. Another reason is that there seems to be a large constraint on the structure of the resistance enzyme to be able to bind substrate well and yet avoid binding the structurally very similar sulfonamide inhibitor. The dihydropteroate synthase products of sul1 and sul2 both show low $\mathrm{K}_{\mathrm{m}}$ values $(0.6 \mu \mathrm{M})$ for PABA, while resisting very high concentrations of sulfonamide (Fig. 4, upper part). The enzyme from sul2 seems to distinguish, with particular acuity, between its normal PABA substrate and the inhibitor.

In contrast, plasmid-mediated trimethoprim resistance is represented by quite a few foreign genes coding for trimethoprim-resistant DHFRs. Almost 20 genes expressing such enzymes are now known, and the list is growing. They are consecutively numbered from $d f r 1$ onwards, since this was the first gene observed [35]. These genes for druginsensitive enzymes must have moved horizontally into pathogenic bacteria from other microorganisms, but their exact origin is not known in any case. A phylogenetic tree relating different DHFRs and based on amino acid alignment and parsimony analysis [38] is shown in Figure 5. It can be seen, that apart from $d f r 1, d f r 5, d f r 6, d f r 7$, and $d f r 14$, which form a well-supported group of similar enzymes, the trimethoprim resistance gene products are diverse and scattered all over the tree. This is consistent with the idea that these resistance genes originate from a wide variety of organisms. Their wide-spread occurrence among pathogenic bacteria could be explained by the fact that most of them are located on integron cassettes, which via the integron mechanism are very horizontally mobile $[19,37]$. The most prevalent trimethoprim resistance gene among Gram-negative bacteria seems to be $d f r 1$, which occurs in a cassette in both class 1 and class 2 integrons. Its class 2 integron carrier, transposon $\operatorname{Tn} 7$, has spread very successfully, mainly due to its high-frequency insertion into a preferred site on the chromosome of $E$. coli and many other bacterial species [19]. Among clinically isolated trimethoprim-resistant bacteria, Tn7 is usually located on the chromosome and less frequently on plasmids [16].

The DHFRs expressed from trimethoprim resistance genes $2 \mathrm{a}, 2 \mathrm{~b}$ and $2 \mathrm{c}$ are excluded from the phylogenetic tree shown in Figure 5, because they are completely unrelated in terms of polypeptide structure and enzyme kinetics to other DHFRs in prokaryotes and eukaryotes [19]. They are, however closely related among themselves with 78 to $86 \%$ amino acid identity, and are extremely resistant to trimethoprim $\left(\mathrm{IC}_{50} \mathrm{~s}>1 \mathrm{mM}\right)[3,11,44]$. The question of their origin is intriguing, and has not yet found an answer.

One of the resistance genes in the phylogenetic tree, $d f r 9$ (Fig. 5), was originally found in isolates of $E$. coli from swine, where it occurred on large transferable plasmids [20]. The $d f r 9$ gene was observed at a frequency of $11 \%$ among trimethoprimresistant veterinary isolates of $E$. coli, but only very rarely among corresponding human isolates (one was found among 434 tested isolates) [21]. Although the origin of $d f r 9$ is unknown, its spread among swine bacteria could be due to the frequent veterinarian prescription of trimethoprim in swine rearing. A subsequent spread into commensal bacteria in humans might then have taken place $[17,25]$. Further scrutiny of $d f r 9$ and its surroundings in many plasmids 
Resistance to trimethoprim and sulfonamides

267

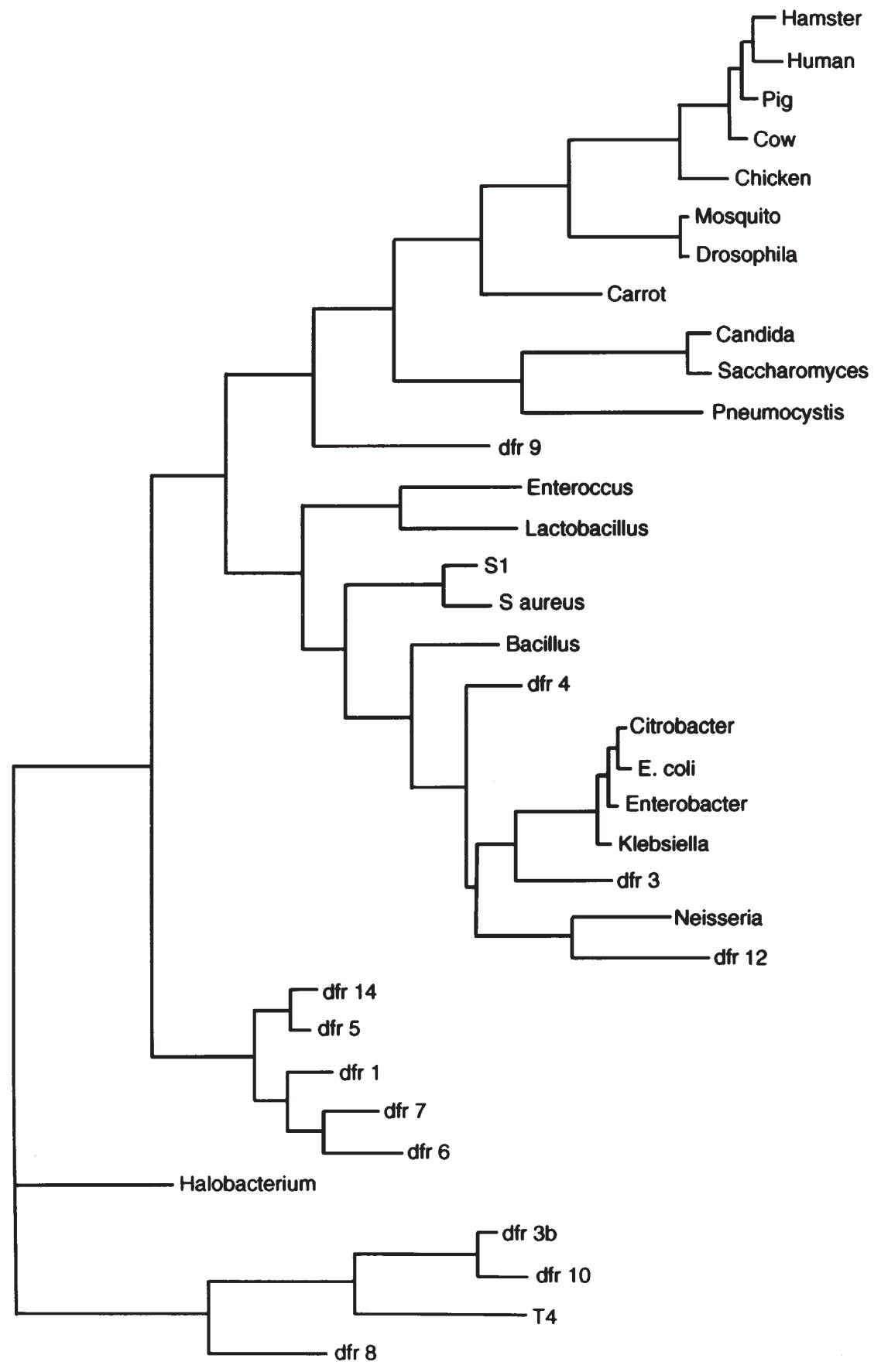

Figure 5. Phylogenetic tree relating dihydrofolate reductase from different sources, based on amino acid alignment and parsimony analysis (adapted from [38]). Resistance-mediating enzymes are marked by der and a number. 


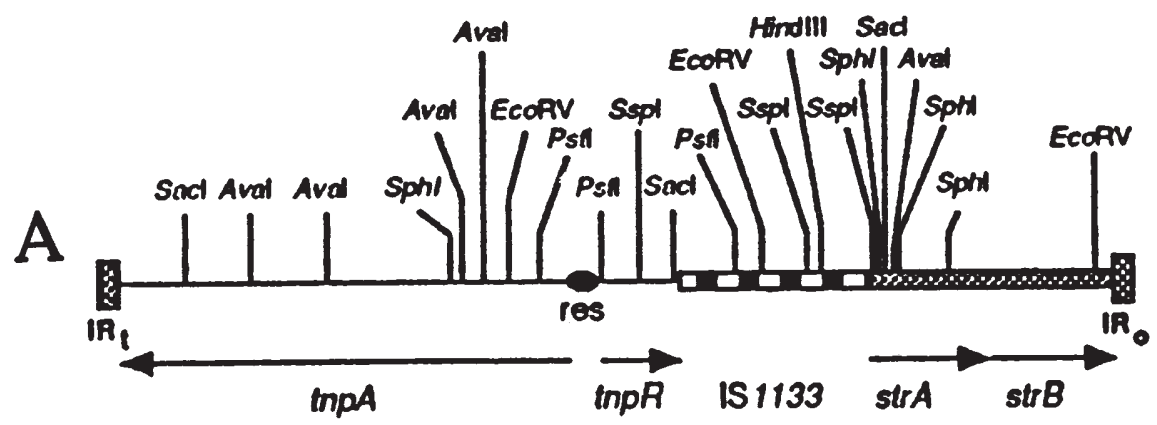

B

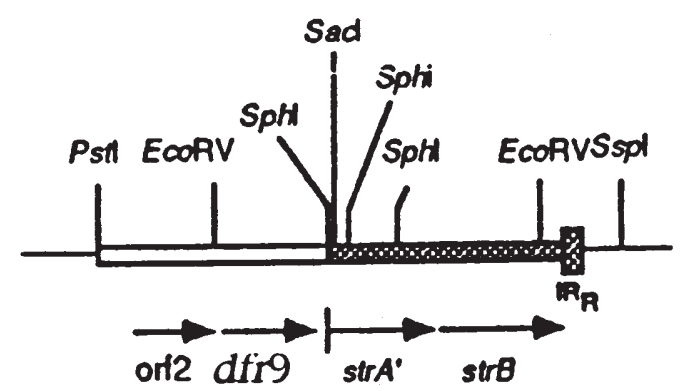

Figure 6. (A) Restriction enzyme digestion map of Tn 5393 with transposition genes $\operatorname{tnpA}$, tnp R and res, and also the insertion sequence IS1133 and streptomycin resistance genes strA and str $\mathrm{B}$ marked out. (B) The trimethoprim-resistance gene $d f r 9$ was found inserted in the right-hand end segment of transposon Tn5393; str $\mathrm{A}^{\prime}$ is strA truncated by dfr9; orf 2 is an open reading frame (510 bp) of unknown function.

from several strains revealed that it was borne on a disabled transposon, Tn5393, which had earlier been found on a plasmid in the plant pathogen Erwinia amylovora, causing fire blight on apple trees [4]. This transposon carries two streptomycin resistance genes, strA and strB (Fig. 6A), and it could be surmised that it evolved under the heavy selection pressure of streptomycin, ubiquitously used for control of the mentioned plant disease in many countries [27, 36]. The $d f r 9$ gene was found inserted in the strA gene together with an unknown ORF (orf2) at the right-hand end of Tn5393 and substituting for IS1133 (Fig. 6B). The inserted $d f r 9$ truncates 119 nucleotides of the strA gene inactivating both strA and
strB, which have to be expressed together for drug resistance [32]. The occurrence of $d f r 9$, expressing trimethoprim resistance in E. coli from swine in Sweden, and its localization on a genetic mobilization structure closely related to transposon Tn5393 originally observed to mediate streptomycin resistance in a plant pathogen in the USA - could be regarded as a powerful demonstration of bacterial adaptation to the heavy use of antibacterial agents in agriculture and stock breeding. Modern pig rearing in large stables with big animal herds could be looked at as gigantic genetic laboratories in that they create very large populations of genetically communicating bacteria. This would also allow very rarely occurring 
genetic events to surface, like mobilizing a trimethoprim resistance gene, under selection pressure from the heavy use of this drug in animal husbandry.

The $d f r 9$ gene has recently been observed in further human pathogens. It was found in Campylobacter jejuni, where it was located on the chromosome, and in a Tn5393 context as described above [12]. It ought to be mentioned here, that Campylobacter jejuni is a commensal in the gut of swine. Moreover, the $d f r 1$ gene was found on the chromosome of Campylobacter jejuni $[12,14]$, where it appeared as a cassette in connection with integrases characteristic of both class 1 and class 2 integrons.

Further $d f r$ genes mediating trimethoprim resistance have been reported lately. One of these, $d f r 13$, was found as a cassette in a class 1 integron context [2]. Another example is the occurrence of an additional drug-resistant DHFR in E. faecalis expressed from an acquired, chromosomally located $d f r$ gene [5].

\section{CHROMOSOMAL RESISTANCE TO TRIMETHOPRIM}

Resistance to trimethoprim due to mutational changes in the intrinsic $d f r$ gene has been reported in several pathogens. One example of this is a clinical isolate of $E$. coli found to be highly resistant to trimethoprim by combining a several hundred-fold overproduction of the chromosomal DHFR with an increase in the $\mathrm{K}_{\mathrm{i}}$ value for the drug [10]. Enzyme overproduction was explained by a combination of four different mutational effects. One effect was a promoter-up mutation in the -35 region, and a second effect was a $1 \mathrm{bp}$ increase in the distance between the -10 region and the start codon. Furthermore, there were several mutations optimizing the ribosome-binding site and also several mutations in the structural gene leading to more frequently used codons. A mutational change of a glycine for a tryptophan at position 30 in the structural gene was thought to effect the three-fold increase in the $\mathrm{K}_{\mathrm{i} \text { value }}$ for trimethoprim. All these changes represent a remarkable evolutionary adaptation to the presence of antifolates like trimethoprim.

A similar type of chromosomal resistance to trimethoprim has been found in Haemophilus influenzae, where differences both in the promoter region and the structural gene were observed between trimethoprim-susceptible and trimethoprim-resistant isolates [6]. Several changes were observed in different parts of the structural gene in different isolates including the C-terminal part not known to participate in the binding of substrates or inhibitors. It was speculated that these changes lead to an altered secondary structure of the enzyme causing a loss or a decrease in trimethoprim binding, in turn resulting in a trimethoprim resistance phenotype. Besides, in Streptococcus pneumoniae, patterns of amino acid changes, varying between different isolates and leading to trimethoprim resistance, have been observed [1]. In this investigation there was also evidence for a horizontal spread of resistance-mediating gene fragments, carrying the mentioned patterns of amino acid changes, by heterologous recombination, most likely between closely related streptococcal species.

There is also an indirect mechanism for low-level resistance to trimethoprim, effected by the mutational loss in bacteria of their ability to methylate deoxyuridylic acid to thymidylic acid, making them dependent on an external supply of thymine $[15,22]$. The inactivated thymidylate synthase, compensated for by thymine from the environment, relieves the cellular DHFR from its major task of regenerating tetrahydrofolate in the formation of $\mathrm{N}^{5}, \mathrm{~N}^{10}$ - methylene tetrahydrofolate which is oxidized in the deoxyuridylate methylation process. This means that the cell can afford to have a fraction of its dihydrofolate reductase inactivated by trimethoprim. 


\section{CHROMOSOMAL RESISTANCE TO SULFONAMIDES}

As mentioned above, sulfonamides interfere with the formation of folic acid in bacteria, by competitively inhibiting the bacterial enzyme dihydropteroate synthase. A simple mechanism of resistance would consist of mutational changes in the chromosomal gene $(f o l P)$ for dihydropteroate synthase, resulting in a lowered affinity for the inhibiting sulfonamide in the expressed enzyme. Spontaneous mutants of $E$. coli showing sulfonamide resistance by a single basepair substitution in folP were isolated in the laboratory $[33,34,42]$. With the dihydropteroate synthase in one of these mutants, which was also temperature-sensitive, the $\mathrm{K}_{\mathrm{i}}$ value for sulfathiazole binding was found to be increased 150-fold, while the $\mathrm{K}_{\mathrm{m}}$ for the PABA substrate showed a ten-fold increase $[40,41]$. The higher $\mathrm{K}_{\mathrm{m}}$ for PABA, resulting in a less efficient enzyme could be looked at as a trade-off for resistance. Similarly a spontaneous laboratory sulfonamideresistant mutant of Streptococcus pneumoniae was shown to contain a 6-nucleotide repeat in its fol $P$ gene, effecting a repeat of amino acids Ile-Glu, in turn extending the helical structure of the enzyme protein by two residues, thus considerably altering the tertiary structure of the enzyme making it drug resistant [24]. Similar duplications at several distinct locations including that mentioned above were later observed in clinical isolates of sulfonamide-resistant Streptococcus pneumoniae from many parts of the world [34]. It was also shown that deletions of the 6 bp repetition by site-directed mutagenesis resulted in a drug-sensitive enzyme with kinetic characteristics indistinguishable from those of an enzyme from a sulfonamide susceptible reference strain. This could be interpreted to mean that the $6 \mathrm{bp}$ insertion is a necessary and sufficient condition for sulfonamide resistance in strains of Streptococcus pneumoniae. There are two more examples of relatively simple mutational changes in the folP gene medi- ating sulfonamide resistance in pathogenic bacteria, one of which is Campylobacter jejuni. The folP gene, for the sulfonamide target in this organism is the largest characterized so far. Its dihydropteroate synthase product consists of 390 amino acid residues, and this enzyme showed differences in four amino acid residues (Leu186Phe; Asp238Asn; Asn245Lys; Phe246Tyr) in sulfonamide-resistant clinical isolates of Campylobacter jejuni [13]. The four mentioned mutations were shown to mediate a dramatic effect on the affinity of the enzyme for sulfonamide (sulfathiazole). The $\mathrm{K}_{\mathrm{i}}$ value was estimated to $500 \mu \mathrm{M}$ for the resistance enzyme as compared to $0.5 \mu \mathrm{M}$ for the susceptible enzyme [13].

Another very recent example is Haemophilus influenzae. In sulfonamide resistant isolates of this pathogen, the folP gene contained a 12 bp insertion encoding for Phe-Leu-Tyr-Asn at position 65 of the protein. Amino acid residue 65 itself was furthermore found to be changed from Asn to Ser in resistant strains. These changes were absent from susceptible isolates including the H. influenzae $\mathrm{Rd}$ reference strain [8].

Clear evidence for a horizontal transfer of chromosomally borne resistance to sulfonamides was found in the pathogens Streptococcus pyogenes and Neisseria meningitidis. Streptococcal infections generally used to be effectively treated with sulfonamide when it was introduced as an antibacterial agent more than 65 years ago. Failures due to resistance were observed, however [34]. When penicillin came into use around 1940, it replaced sulfonamide since it was more effective and caused fewer side effects in the treatment of streptococcal infections. Sulfonamide-resistant strains of $S$. pyogenes seem to have been prevalent for decades after the use of this drug against streptococcal disease had ceased. The folP gene was observed to be substantially altered in highly resistant members of this group of isolates [43]. There were 111 altered nucleotides resulting in 30 amino acid changes when folP in susceptible and 
resistant strains were compared. These differences are too large to be accounted for by accumulated mutations. Instead, the resistance gene has most likely been introduced by transformational recombination. This interpretation is supported by the observation that the neighbouring gene, folE (encoding GTP cyclohydrolase) also showed a substantial divergence. At the ends of this mosaic segment, nucleotide divergence dropped from $16.8 \%$ to $0.8 \%$. The latter figure probably reflects natural strain variation. Kinetic studies on the dihydropteroate synthase from a resistant strain showed an almost 140 -fold increase in $\mathrm{K}_{\mathrm{i}}$ when compared to the enzyme from a susceptible strain, while $\mathrm{K}_{\mathrm{m}}$ for PABA exhibited an approximately four-fold increase. It is interesting that the resistant strain has survived in the absence of a selection pressure from clinically used sulfonamides, despite having the disadvantage of carrying a less efficient folate-synthesizing enzyme.

Moreover, the pathogen Neisseria meningitidis used to be heavily exposed to sulfonamide in earlier times, when this drug was extensively used in both treatment and prophylaxis of meningococcal disease. As with $S$. pyogenes, sulfonamide resistance is commonly found among pathogenic strains of Neisseria meningitidis in spite of the fact that sulfonamide has not been used against these bacteria for decades. On close study of $f o l P$, astonishingly large differences were found between resistant and susceptible strains of $N$. meningitidis [23, 31]. Two classes of resistance determinants were found by sequence characterization of folP from several clinical isolates. In one of these classes, the folP gene was about $10 \%$ different from that in a susceptible isolate indicating recombination rather than accumulation of point mutations as a source of resistance. In this class of resistant variants, strains were found, in which only the central part of folP showed the $10 \%$ difference characteristic of the resistance gene. By contrast, the N-terminal and C-terminal parts of the translated protein were identical to those of susceptible isolates, that is, these strains carry a mosaic resistance gene. A distinguishing feature of this class of resistance genes is an insertion of six nucleotides, mediating the insertion of two amino acid residues, Ser-Gly, in a highly conserved part of the enzyme. The removal of this insert by site-directed mutagenesis results in susceptibility [9]. The other mentioned class of sulfonamide resistance determinants in $N$. meningitidis showed a lower degree of difference to the folP gene from susceptible isolates, and lacked the $6 \mathrm{bp}$ insert. Several of these resistance-mediating folP genes were identical among themselves but distinct from those of susceptible isolates. This identity of resistance determinants again indicates a horizontal gene transfer followed by homologous recombination [9]. Amino acid differences between the dihydropteroate synthases from resistant and susceptible strains of Neisseria meningitidis were systematically studied by site-directed mutagenesis. When resistance changes in three highly conserved amino acid residues of the second class of resistant isolates were mutated back to consensus type, and the SerGly insertion removed from the enzyme of the first class, the $\mathrm{K}_{\mathrm{i}}$ values and correlating MIC data were changed to those of susceptible strains [34]. However, most of these changes to susceptibility severely interfered with enzyme efficiency, reflected in elevated $\mathrm{K}_{\mathrm{m}}$ values, which in turn could be lowered by compensating mutations [34]. The structural differences of the resistance enzymes thus seem to be more complicated than the described amino acid changes. This could be interpreted to mean that the resistance genes have evolved in other bacterial species and later moved into Neisseria meningitidis by transformation and recombination.

\section{CONCLUSION}

Sulfonamides and trimethoprim have served for decades as efficient and inexpensive remedies in the treatment of 
bacterial infections in animals and man. The development of resistance has gradually impinged on their use. Furthermore, the adaptation of resistant bacterial strains to the trade-off costs of resistance means that susceptibility will not return upon suspension of drug use. Folate metabolism could, however, also be a good target in the future for inexpensive antibacterial drugs. The pterin pyrophosphate substrate of dihydropteroate synthase could be interesting in this respect. It binds to a very well conserved part of the enzyme.

\section{REFERENCES}

[1] Adrian P.V., Klugman K.P., Mutations in the dihydrofolate reductase gene of trimethoprimresistant isolates of Streptococcus pneumoniae, Antimicrob. Agents Chemother. 41 (1997) 24062413.

[2] Adrian P.V., Thomson C.J., Klugman K.P., Amyes S.G.B., New gene cassettes for trimethoprim resistance, dfr13, and streptomycin-spectinomycin resistance, $\operatorname{ard} \mathrm{A} 4$, inserted on a class 1 integron, Antimicrob. Agents Chemother. 44 (2000) 355-361.

[3] Brisson N., Hohn T., Nucleotide sequence of the dihydrofolate reductase gene borne by the plasmid R67 and conferring methotrexate resistance, Gene 28 (1984) 271-275.

[4] Chiou C.S., Jones A.L., Nucleotide sequence analysis of a transposon (Tn 5393) carrying streptomycin resistance genes in Erwinia amylovora and other Gram-negative bacteria, J. Bacteriol. 175 (1993) 732-740.

[5] Coque T.M., Singh K.V., Weinstock G.M., Murray B.E., Characterization of dihydrofolate reductase genes from trimethoprim-susceptible and trimethoprim-resistant strains of Enterococcus faecalis, Antimicrob. Agents Chemother. 43 (1999) 141-147.

[6] de Groot R., Sluijter M., de Bruyn A., Camps J., Goessens W.H.F., Smith A.L., Hermans P.W.M., Genetic characterization of trimethoprim resistance in Haemophilus influenzae, Antimicrob. Agents Chemother. 40 (1996) 2131-2136.

[7] Domagk G., Beitrag zur Chemotherapie der bakteriellen Infektionen, Dtsch. Med. Wochenschr. 7 (1935) 250-253

[8] Enne V.J., Livermore D.M., Hall L.M.C., Sulfonamide resistance in Haemophilus influenzae mediated by sul 2 or an insertion in chromosomal folP. Abstract, 40th Interscience Conference on Antimicrobial Agents and Chemotherapy, p. 130, abstract no. 2275, 2000.

[9] Fermér C., Kristiansen B.-E., Sköld O., Swedberg G., Sulfonamide resistance in Neisseria menin- gitidis as defined by site-directed mutagenesis could have its origin in other species, J. Bacteriol. 177 (1995) 4669-4675.

[10] Flensburg J., Sköld O., Massive overproduction of dihydrofolate reductase as a response to the use of trimethoprim, Eur. J. Biochem. 162 (1987) 473-476.

[11] Flensburg J., Steen R., Nucleotide sequence analysis of the trimethoprim resistant dihydrofolate reductase encoded by R plasmid R751, Nucleic Acids Res. 14 (1986) 5933.

[12] Gibreel A., Sköld O., High-level resistance to trimethoprim in clinical isolates of Campylobacter jejuni by acquisition of foreign genes ( $d f r l$ and $d f r 9$ ) expressing drug-insensitive dihydrofolate reductases, Antimicrob. Agents Chemother. 42 (1998) 3059-3064.

[13] Gibreel A., Sköld O., Sulfonamide resistance in clinical isolates of Campylobacter jejuni: mutational changes in the chromosomal dihydropteroate synthase, Antimicrob. Agents Chemother. 43 (1999) 2156-2160.

[14] Gibreel A., Sköld O., An integron cassette carrying $d f r 1$ with 90 -bp repeat sequences located on the chromosome of trimethoprim-resistant isolates of Campylobacter jejuni, Microb. Drug Resist. 6 (2000) 91-98.

[15] Hamilton-Miller J.M.T., Resistance to antibacterial agents acting on folate metabolism, in: Bryan L.E. (Ed.), Antimicrobial drug resistance, Academic Press, Inc., New York, 1984, pp. 173190.

[16] Heikkilä E., Sundström L., Skurnik M., Huovinen P., Analysis of genetic localization of the type I trimethoprim resistance gene from Escherichia coli isolated in Finland, Antimicrob. Agents Chemother. 35 (1991) 1562-1569.

[17] Hummel R., Tschäpe H., Witte W., Spread of plasmid-mediated nourseothricin resistance due to antibiotic use in animal husbandry, J. Basic Microbiol. 26 (1986) 461-466.

[18] Huovinen P., Trimethoprim resistance, Antimicrob. Agents Chemother. 31 (1987) 1451-1456.

[19] Huovinen P., Sundström L., Swedberg G., Sköld O., Trimethoprim and sulfonamide resistance, Antimicrob. Agents Chemother. 39 (1995) 279289.

[20] Jansson C., Sköld O., Appearance of a new trimethoprim resistance gene, $d h f r \mathrm{IX}$, in Escherichia coli from swine, Antimicrob. Agents Chemother. 35 (1991) 1891-1899.

[21] Jansson C., Franklin A., Sköld O., Spread of a new trimethoprim resistance gene, dhfrIX, among porcine isolates and human pathogens, Antimicrob. Agents Chemother. 36 (1992) 2704-2708.

[22] King C.H., Shlaes D.M., Dul M.J., Infection caused by thymidine-requiring, trimethoprimresistant bacteria, J. Clin. Microbiol. 18 (1983) 79-83.

[23] Kristiansen B.-E., Rådström P., Jenkins A., Ask E., Facinelli B., Sköld O., Cloning and characterization of a DNA fragment that confers sulfonamide resistance in a serogroup $B$, serotype 
15 strain of Neisseria meningitidis, Antimicrob. Agents Chemother. 34 (1990) 2277-2279.

[24] Lopez P., Espinosa M., Greenberg B., Lacks S.A., Sulfonamide resistance in Streptococcus pneumoniae: DNA sequence of the gene encoding dihydropteroate synthase and characterization of the enzyme, J. Bacteriol. 169 (1987) 4320-4326.

25] Marshall B., Petrowski D., Levy S. B., Inter and intraspecies spread of Escherichia coli in a farm environment in the absence of antibiotic usage, Proc. Natl. Acad. Sci. USA 87 (1990) 6609-6613.

[26] Matthews D.A., Bolin J.T., Burridge J.M., Filman D.J., Volz K.W., Kraut J., Dihydrofolate reductase. The stereochemistry of inhibitor selectivity, J. Biol. Chem. 260 (1985) 392-399.

[27] McManus P.S., Antibiotic use in plant disease control, APUA (Alliance for the Prudent Use of Antibiotics) Newsletter 17 (1999) 1-3.

[28] Odensvik K., Sales of antibacterial and antiparasitic agents for veterinary purposes (in Swedish), Svensk Veterinärtidning 52 (2000) 445-448.

[29] Rådström P., Swedberg G., RSF1010 and a conjugative plasmid contain $s u l 2$, one of the two known genes for plasmid-borne sulfonamide resistance dihydropteroate synthase, Antimicrob. Agents Chemother. 32 (1988) 1684-1692.

[30] Rådström P., Swedberg G., Sköld O., Genetic analyses of sulfonamide resistance and its dissemination in gram-negative bacteria illustrate new aspects of R plasmid evolution, Antimicrob. Agents Chemother. 35 (1991) 1840-1848.

[31] Rådström P., Fermér C., Kristiansen B.-E., Jenkins A., Sköld O., Swedberg G., Transformational exchanges in the dihydropteroate synthase gene of Neisseria meningitidis: a novel mechanism for acquisition of sulfonamide resistance, J. Bacteriol. 174 (1992) 6386-6393.

32] Scholz P., Haring V., Wittmann-Liebold B., Ashmann K., Bagdasarian M., Scherzinger E., Complete nucleotide sequence and gene organization of the broad host range plasmid RSF1010, Gene 75 (1989) 271-288.

[33] Sköld O., R-factor-mediated resistance to sulfonamides by a plasmid-borne drug-resistant dihydropteroate synthase, Antimicrob. Agents Chemother. 9 (1976) 49-54.

[34] Sköld O., Sulfonamide resistance: mechanisms and trends, Drug Res. Updates 3 (2000) 155-160.

[35] Sköld O., Widh A., A new dihydrofolate reductase with low trimethoprim sensitivity induced by an $\mathrm{R}$-factor mediating high resistance to trimethoprim, J. Biol. Chem. 249 (1974) 4324-4325.

[36] Sundin G.W., Bender C.L., Dissemination of the strA-strB streptomycin resistance genes among commensal and pathogenic bacteria from humans, animals and plants, Mol. Ecol. 5 (1996) 133-143.

[37] Sundström L., Rådström P., Swedberg G., Sköld O., Site-specific recombination promotes linkage between trimethoprim- and sulfonamide-resistance genes. Sequence characterization of $d f r 5$ and sul 1 and a recombination active locus of Tn21, Mol. Gen. Genet. 213 (1988) 191-201.

[38] Sundström L., Jansson C., Bremer K., Heikkilä E., Olsson-Liljequist B., Sköld O., A new dhfrVIII trimethoprim resistance gene, flanked by IS26, whose product is remote from other dihydrofolate reductases in parsimony analysis, Gene 154 (1995) 7-14

[39] Swaney S.M., Aoki H., Ganoza M.C., Shinabarger D.L., The oxazolidinone linezolid inhibits initiation of protein synthesis in bacteria, Antimicrob. Agents Chemother. 42 (1998) 3251-3255.

[40] Swedberg G., Sköld O., Plasmid-borne sulfonamide resistance determinants studied by restriction enzyme analysis, J. Bacteriol. 153 (1983) 1228-1237.

[41] Swedberg G., Castensson S., Sköld O., Characterization of mutationally altered dihydropteroate synthase and its ability to form a sulfonamidecontaining dihydrofolate analog, J. Bacteriol. 137 (1979) 129-136.

[42] Swedberg G., Fermér C., Sköld O., Point mutations in the dihydropteroate synthase gene causing sulfonamide resistance, Adv. Exp. Med. Biol. 338 (1993) 555-558.

[43] Swedberg G., Ringertz S., Sköld O., Sulfonamide resistance in Streptococcus pyogenes is associated with differences in the amino acid sequence of its chromosomal dihydropteroate synthase, Antimicrob. Agents Chemother. 42 (1998) 10621069.

[44] Swift G., Mc.Carthy B.J., Heffron F., DNA sequence of a plasmid-encoded dihydrofolate reductase, Mol. Gen. Genet. 181 (1981) 441-447.

[45] Van Treeck U.F., Schmidt F., Wiedemann B., Molecular nature of a streptomycin and sulfonamide resistant plasmid (pBP1) prevalent in clinical Escherichia coli strains and integration of an ampicillin resistance transposon (TnA), Antimicrob. Agents Chemother. 19 (1981) 371-380.

[46] Wise E.M. Jr., Abou-Donia M.M., Sulfonamide resistance mechanism in Escherichia coli: R-plasmids can determine sulfonamide-resistant dihydropteroate synthases, Proc. Natl. Acad. Sci. USA 72 (1975) 2621-2625. 